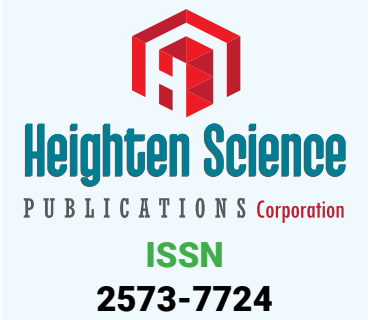

*Address for Correspondence: Atteyat A Labib, Department Experimental Nuclear Physics, Nuclear Research Center, Atomic Energy Authority of Egypt, Cairo 13759, Egypt, Email: mhmodaa@qu.edu.sa

Submitted: 18 December 2017

Approved: 23 December 2017

Published: 26 December 2017

Copyright: @ 2017 Labib AA, et al. This is an open access article distributed under the Creative Commons Attribution License, which permits unrestricted use, distribution, and reproduction in any medium, provided the original work is properly cited

Keywords: Benzofuran; pyridine derivative; lodine-125; Biological distribution
Research Article

\section{Synthesis, Radioiodination and Biological distribution of 5-(5-(tributylstannyl) benzofuran-2-yl) pyridin-2-amine as an amyloid imaging agent}

\author{
Atteyat A Labib ${ }^{1,2 *}$ and Mohsen B Challan ${ }^{1,3}$ \\ 'Department Experimental Nuclear Physics, Nuclear Research Center, Atomic Energy Authority \\ of Egypt, Cairo 13759, Egypt \\ 2Department of Food Science \& Human Nutrition, College of Agriculture \& Veterinary Medicine, \\ Qassim University, Buraydah 52383, Saudi Arabia \\ ${ }^{3}$ Department of Physics, College of Science, Majmaah University, Majmaah 11952, Saudi Arabia
}

\section{Abstract}

In this work an efficient method developed for the synthesis of ${ }^{125}$-benzofuran-2-yl) pyridin-2-amine ( ${ }^{25}$ IBPA), followed by radioiodination with ${ }^{125}$ by using Chloramine-T at $\mathrm{pH}$ 8. The reaction proceeds within $10 \mathrm{~min}$ at room temperature $\left(20-25^{\circ} \mathrm{C}\right)$. The radiochemical yield determined by Thin-Layer Chromatography (TLC) using hexane:ethyl acetate $(1: 6 \mathrm{~V} / \mathrm{v})$ and the purity analyzed by high-performance liquid chromatography using a reversed-phase RP18column and acetonitrile:0.1 M ammonium bicarbonate $(\mathrm{pH} 7.5)(1: 1)$ as the mobile phase at a flow rate of $1 \mathrm{ml} \times \mathrm{min}^{-1}$. The radiochemical yield using $\mathrm{aH}_{2} \mathrm{O}_{2}$ oxidant found equal to $96.5 \%$ with a radiochemical purity of ${ }^{125}$ - $\mathrm{BPA}$ of over $96.5 \%$. The biodistribution data in normal mice indicated a high initial uptake of $6.54 \pm 0.10(\% \mathrm{ID} / \mathrm{g} \pm \mathrm{SD})$ in the brain within $30 \mathrm{~min}$ post-injection. These results promote a further the use of ${ }^{125}$-BPA as a novel agent for brain imaging.

\section{Introduction}

Pyridine derivatives of different heterocyclic nuclei have potent pharmacological properties including antifungal [1], antitubercular [2], antibacterial [3], antimicrobial [4-7], and insecticidal [8]. Heterocyclic Mannich bases are well known and important nitrogen compounds. Several methods have been applied for their synthesis. Most of the derivatives of heterocyclic Mannich bases have been found to possess considerable biological activities [9]. Alzheimer 's disease (AD) is a leading cause of dementia with symptoms that include cognitive decline, irreversible memory loss, disorientation, language impairment, and an inability to carry out normal daily functions. Currently, it is difficult for clinicians to differentiate between the cognitive decline associated with normal aging and that associated with $\mathrm{AD}$ [10]. A definitive diagnosis of AD can only be established by postmortem histopathological examination [11]. Postmortem brains of AD patients reveal neuropathological features including Senile Plaques (SPs) and Neuro-Fibrillary Tangles (NFTs), which contain $\beta$-Amyloid (A $\beta$ ) peptides and highly phosphorylated tau proteins, respectively [12]. Although several radioiodinated or ${ }^{99 \mathrm{~m}} \mathrm{Tc}$-labeled ligands for $\mathrm{A} \beta$ plaques have been reported, unfavorable pharmacokinetics including low uptake into the brain and slow washout have prevented clinical studies. [ $\left.{ }^{123} \mathrm{I}\right]$-6-iodo-2-(4'-dimethylamino)phenyl-imidazo[1,2-a]pyridine (IMPY) is the first Single Photon Emission Tomography (SPECT)imaging agent to be tested in humans [13]. Although [ $\left.{ }^{123} I\right]-I M P Y$ showed excellent properties as an A $\beta$ imaging probe in preclinical studies, the preliminary clinical data displayed a low signal-to-noise ratio, making it difficult to distinguish $\mathrm{AD}$ patients, possibly because of its high lipophilicity and low 
stability in vivo. Therefore, there is no SPECT imaging probe useful for the clinical diagnosis of $\mathrm{AD}$ [14]. In this work, a simple method for syntheses and radioiodination of ${ }^{125}$ I-BPA was studied. A preliminary in vivo study of ${ }^{125}$ I-BPA in normal mice was completed to elucidate the biological behavior of this labeled compound.

\section{Experimental}

\section{Experimental materials}

The following instruments and materials were used. A gamma counter (Nucleous Model 2010, Oak Ridge, USA), connected with a well type NaI(Tl) crystal. The HighPerformance Liquid Chromatography (HPLC) machine [Sykam Model] was equipped with a S-2100 solvent delivery system, a S-5111 injector valve bracket, a UV/VIS spectrophotometric detector S-3240 and a C-18 Lichrosorb analytical column (250 $\mathrm{mm} \times 4-6 \mathrm{~mm}, 5 \mathrm{~mm}$ inner diameter). All melting points were determined on an electrothermal melting point apparatus and are uncorrected. IR spectra were recorded (KBr discs) on a Shimadzu FT-IR-8201 PC spectrophotometer (Kyoto, Japan). ${ }^{1} \mathrm{H}-\mathrm{NMR}$ and ${ }^{13} \mathrm{C}$-NMR spectra were recorded in $\mathrm{CDCl}_{3}$ and $\left(\mathrm{CD}_{3}\right)_{2} \mathrm{SO}$ solutions on a Varian Gemini $300 \mathrm{MHz}$ (Varian Inc., Palo Alto, CA) and JNM-LA 400 FT-NMR system spectrometer (Japan Electronic Optics Laboratory Co. Ltd., Tokyo, Japan) and chemical shifts are expressed in $\delta$ units using TMS as an internal reference. Mass spectra were recorded on a Shimadzu GCMS-QP1000 EX mass spectrometer (70 eV, Shimadzu, Kyoto, Japan). Elemental analyses were carried out at the Micro Analytical Center of the University of Cairo, Giza, Egypt. All other chemicals were purchased from Merck Co. Radioactive iodine-125 was purchased from Institute of Isotopes Co., Ltd. (Budapest, Hungary). Solution $\mathrm{pH}$ was adjusted to $\mathrm{pH} 7$ before use. The ethanol used was $99 \%$ ethanol. To prepare the AgCl-impregnated filter, Whatman No. 3 filter paper $(0=5 \mathrm{~mm}$ and $\mathrm{t}=0.33$ $\mathrm{mm}$ and basis weight $185 \mathrm{gm} / \mathrm{m}$ ) was immersed into a $0.5 \mathrm{~N}$ aqueous solution of $\mathrm{AgNO}_{3}$. After drying in the dark, the filter was immersed into $1 \mathrm{~N} \mathrm{HCl}$ and then repeatedly washed with distilled water up to neutral reaction and kept in the darkness up to use.

\section{Chemical synthesis}

5-Bromobenzofuran-2-yl)pyridin-2-amine(I): Asolution of5-bromobenzofuran2-boronic acid (722 mg, $3.0 \mathrm{mmol}$ ), 2-amino-5-iodopyridine ( $660 \mathrm{mg} 3.0 \mathrm{mmol}$ ), and $\mathrm{Pd}\left(\mathrm{Ph}_{3} \mathrm{P}\right) 4.0 \mathrm{mg}, 0.3 \mathrm{mmol}$ ) in $2 \mathrm{M} \mathrm{Na}_{2} \mathrm{CO}_{3}$ (aq.): dioxane (150 ml 1:1) was stirred under reflux overnight. The mixture was allowed to cool to room temperature, and $1 \mathrm{M} \mathrm{NaOH}(20 \mathrm{ml})$ was added. After extraction with ethyl acetate, the organic phase was dried over $\mathrm{Na}_{2} \mathrm{SO}_{4}$ and filtered. The filtrate was concentrated, and the residue was purified by silica gel chromatography hexane: ethyl acetate $=1: 6)$ to give $273 \mathrm{mg}$ of 1 (31.5 \%). ${ }^{1} \mathrm{H} \mathrm{NMR}\left(400 \mathrm{MHz} \mathrm{CDCl}_{3}\right.$ ): d 4.66 (s, 2H), 6.57 (d, 1H, J=8.4 Hz), $6.79(\mathrm{~s}, 1 \mathrm{H})$, $7.32(\mathrm{~d}, 1 \mathrm{H}, J=2.4 \mathrm{~Hz}), 7.33(\mathrm{~d}, 1 \mathrm{H}, J=2.0 \mathrm{~Hz}), 7.66(\mathrm{~d}, 1 \mathrm{H}, J=1.6 \mathrm{~Hz}), 7.86\left(\mathrm{~d},{ }^{1} \mathrm{H}, J 1=8.8\right.$ $\mathrm{Hz}, J 2=2.4 \mathrm{~Hz}), 8.58\left(\mathrm{~d},{ }^{1} \mathrm{H}, J=2.4 \mathrm{~Hz}\right)$. MS: $m / z 290\left(\mathrm{M}^{+}\right)$.

5-(5-(Tributylstannyl) benzofuran-2-yl) pyridin-2-amine (II): A mixture of 1 (273 mg, $0.95 \mathrm{mmol})$, bis (tributyltin) $(0.8 \mathrm{ml})$, and $\left(\mathrm{Ph}_{3} \mathrm{P}\right)_{4} \mathrm{Pd}(100 \mathrm{mg})$ in a mixed solvent ( $40 \mathrm{ml}, 3: 1$ dioxane/triethylamine mixture) was stirred at $90^{\circ} \mathrm{C}$ overnight. After extraction with ethyl acetate, the organic phase was dried over $\mathrm{Na}_{2} \mathrm{SO}_{4}$ and filtered. The filtrate was concentrated, and the residue was purified by silica gel chromatography (hexane:ethyl acetate $=1: 1)$ to give $115.6 \mathrm{mg}$ of $4(24.6 \%) .{ }^{1} \mathrm{H}$ NMR $\left(400 \mathrm{MHz}, \mathrm{CDCl}_{3}\right)$ :d 0.87-0.91(m, 9H), 1.06-1.10 (m, 6H),1.32-1.39 (m, 6H), 1.54-1.62 (m,6H), $4.75(\mathrm{~s}, 2 \mathrm{H})$, $6.54(\mathrm{~d}, 1 \mathrm{H}, \mathrm{J}=8.0 \mathrm{~Hz}), 6.82(\mathrm{~s}, 1 \mathrm{H}), 7.31(\mathrm{~d}, 1 \mathrm{H}, \mathrm{J}=8.0 \mathrm{~Hz}), 7.47(\mathrm{~d}, 1 \mathrm{H}, \mathrm{J}=8.4 \mathrm{~Hz}), 7.63(\mathrm{~s}, 1 \mathrm{H})$, $7.85(\mathrm{~d}, 1 \mathrm{H}, \mathrm{J} 1=8.4 \mathrm{~Hz}, \mathrm{~J} 2=2.4 \mathrm{~Hz}), 8.59(\mathrm{~d}, 1 \mathrm{H}, \mathrm{J}=2.4 \mathrm{~Hz})$. HRMS $(\mathrm{EI}): \mathrm{m} / \mathrm{z}$ calculated for $\mathrm{C}_{25} \mathrm{H}_{36} \mathrm{~N}_{2} \mathrm{OSn}\left(\mathrm{M}^{+}\right)$500.1849, found 500.1847 figure 1.

Preparation of ${ }^{125}$ I-BPA using chloramine-T (CAT): In a reaction vial, 0-200 $\mu \mathrm{g}$ of chloramine-T(CAT), an oxidizing agent was added to a mixture of 5-(5-(tributylstannyl) benzofuran-2-yl) pyridin-2-amine $\left(10-200 \mu \mathrm{g} / 0.5 \mathrm{ml}\right.$ of EtOH), $5 \mu \mathrm{l}$ of $\mathrm{Na}^{125}$. The 


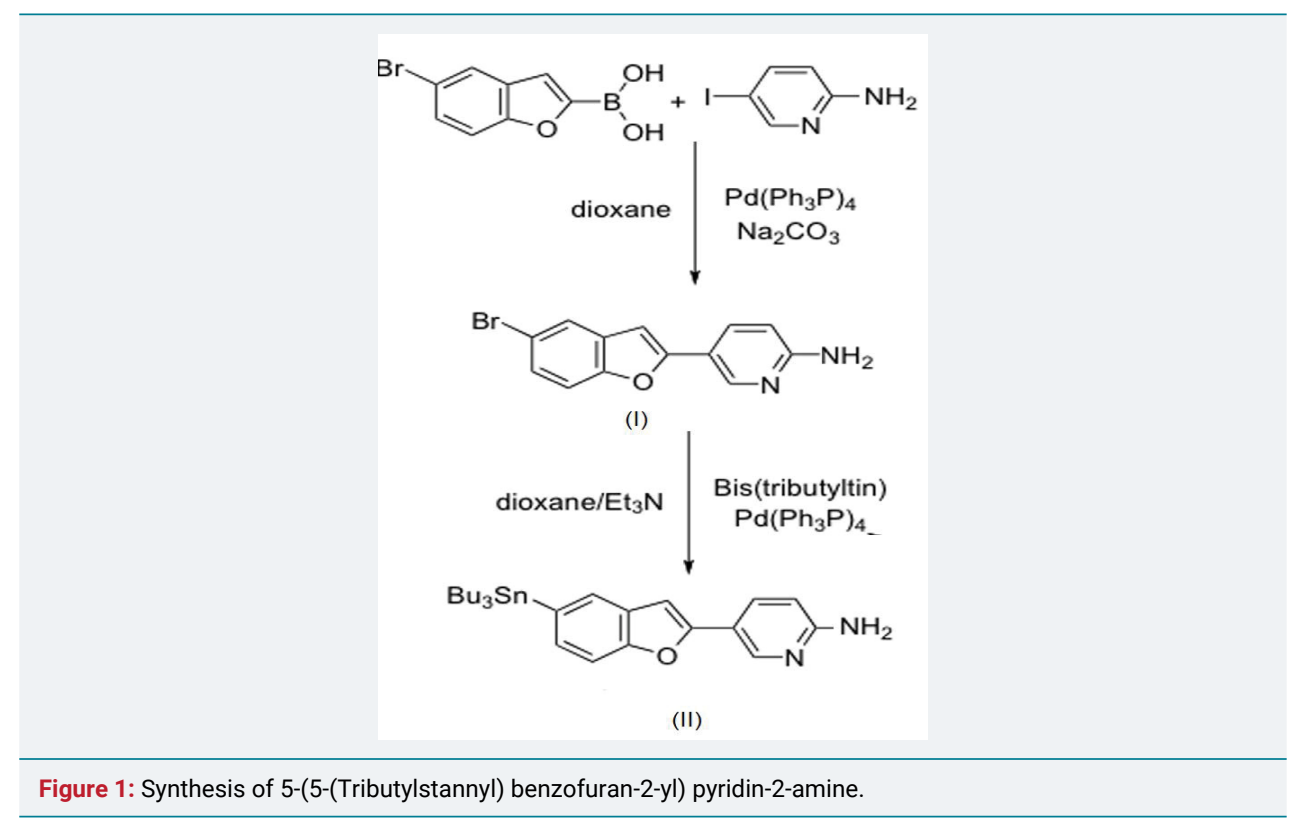

reaction could proceed at room temperature $\left(20-25^{\circ} \mathrm{C}\right)$ for $0-120 \mathrm{~min}$, after which 0.1 $\mathrm{ml} \mathrm{NaHSO}(32 \mathrm{mmol} / \mathrm{L})$ was added to quench the reaction. The reaction mixture was extracted with ethyl acetate and then was passed through an AgCl-impregnated filter [15], followed by a conjugated bacterial filter ( $0.22 \mu \mathrm{m}$ Millipore filter) and subjected to chromatographic analysis.

\section{Chromatographic analysis}

The radiochemical yield and purity of the labeled product, ${ }^{125} \mathrm{I}-\mathrm{BPA}$, were determined by TLC and HPLC as follows. Silica gel G60 on alumina sheets was used for radiochemical yield determination. A $5-\mu \mathrm{L}$ portion of the reaction mixture was placed at $2 \mathrm{~cm}$ from the base and developed using hexane: ethyl acetate $(1: 6 \mathrm{v} / \mathrm{v})$ as the developing solvent. The strips were dried under $\mathrm{N}_{2}$ gas, cut into 1-cm segments, and assayed for radioactivity. The radio-iodinated product, ${ }^{125} \mathrm{I}$-BPA, has an $\mathrm{Rf}=0.7$, whereas ${ }^{125} \mathrm{I}$ has an $\mathrm{Rf}=0.3$. The radiochemical yield was calculated in a similar fashion. Typically, the radiochemical purity of the product was more than $96.5 \%$ by TLC. A $10-\mu \mathrm{L}$ portion of the reaction mixture was injected onto the HPLC column (RP18Lichrosorb) and eluted with acetonitrile $0.1 \mathrm{M}$ ammonium bicarbonate (pH 7.5) (1:1). The retention time (RT) of ${ }^{125}$ I-BPA was $10 \mathrm{~min}$, whereas the RT of ${ }^{125} \mathrm{I}$ was $2 \mathrm{~min}$.

\section{Biological evaluation}

\section{Animals}

Swiss Albino mice weighing 30-35 gm, purchased from the Agriculture Research Center, Cairo, Egypt. The animals were exposed to constant environmental and nutritional conditions throughout the experimental period and were maintained at room temperature $\left(22 \pm 2^{\circ} \mathrm{C}\right)$ with a $12 \mathrm{~h}$ on/off light schedule. Standard access to food and water was provided.

\section{Bio-distribution in normal mice}

Mice were injected directly into a tail vein with $100 \mu \mathrm{l}$ of $10 \% \mathrm{EtOH}$ containing ${ }^{125}$ I-BPA ( $37 \mathrm{kBq}$ ). The mice (male, $\mathrm{n}=5$ for each time point) were sacrificed at 2,10 , 30 , and $60 \mathrm{~min}$ post injection. The organs of interest were removed and weighed, and the radioactivity was measured with a gamma counter. The percentage dose per organ was calculated by comparing the tissue counts to suitably diluted aliquots of the injected material. The \% dose/g of samples was calculated by comparing the sample counts with the count of the diluted initial dose. 


\section{Results and Discussion}

\section{Effect of oxidizing agent}

The effect of the amount of the oxidizing agent CAT on the labeling yield of ${ }^{125}$ I-BPA is demonstrated in figure 2. CAT is a mild oxidizing agent that can oxidize $\mathrm{I}^{-}$into $\mathrm{I}^{+}$ without forming $\mathrm{I}_{2}$. At low amounts of CAT $(10 \mu \mathrm{g})$, the radiochemical yield of ${ }^{125} \mathrm{I}$-BPA was low at $68.9 \%$. A high radiochemical yield of $95.5 \%$ was achieved by increasing the amount of $C A T$ to $250 \mu \mathrm{g}$. Increasing the CAT amount above $250 \mu \mathrm{g}$ led to a decrease in the iodination yield where at $250 \mu \mathrm{g}$ of CAT the decrease in yield may be attributed to the formation of undesirable oxidative byproducts like chlorination. Consequently, $250 \mu \mathrm{g}$ of CAT is highly recommended to avoid the formation of any byproducts and obtain a high labeling yield figure 2 .

\section{Effect of substrate amounts}

The dependence of radiochemical yield on the amount of ${ }^{125} \mathrm{I}-\mathrm{BPA}$ is shown in figure 3. The reaction was performed at different BPA amounts (10-200 $\mu \mathrm{g})$. The radiochemical yield of ${ }^{125}$ I-BPA was only $80 \%$ at $10 \mu \mathrm{g}$ BPA. As the BPA concentration increased, the labeling yield increased to $96.5 \%$ when $100 \mu \mathrm{g}$ of BPA was used. This improvement in yield may be attributed to the fact that $100 \mu \mathrm{g}$ of BPA is sufficient to capture the generated iodonium ion, and as a result, the maximum yield was achieved.

\section{Effect of $\mathrm{pH}$ on the reaction}

The effect of the reaction mixture $\mathrm{pH}$ on the labeling of BPA was studied by varying the $\mathrm{pH}$ from 2 to 10 as shown in figure 4. The experiment was performed using $100 \mu \mathrm{g}$ of BPA. The CAT amount used was $250 \mu \mathrm{g}$, while the other factors were kept constant.

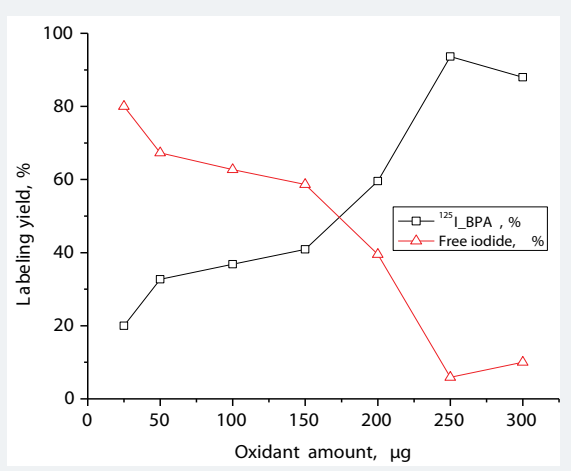

Figure 2: Variation of the radiochemical yield of ${ }^{125}$-BPA as a function of CAT; reaction conditions: $10 \mu \mathrm{l}(3.7 \mathrm{MBq})$ $\mathrm{Na}^{125}, 100 \mu$ l of BPA, various concentrations of $\mathrm{CAT}$ at $\mathrm{pH}$ 8. The reaction mixtures were kept at room temperature for $10 \mathrm{~min}$.

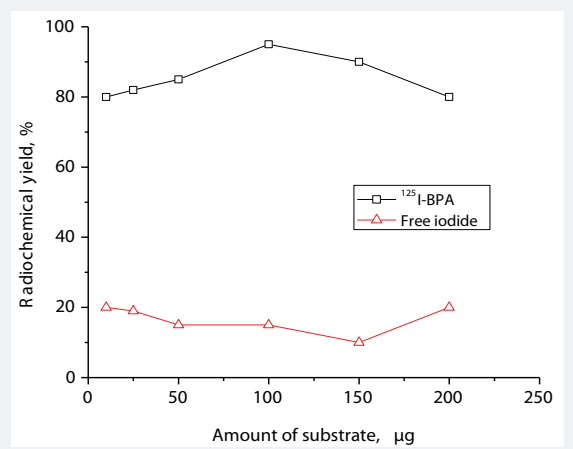

Figure 3: Variation of the radiochemical yield of ${ }^{125}$-BPA as a function of different BPA amounts. The reaction conditions were $10 \mu \mathrm{g}(7.3 \mathrm{MBq}) \mathrm{Na}^{125}$ and $100 \mu \mathrm{g}$ of $\mathrm{CAT}$ at $\mathrm{pH}$ 8. The reaction mixtures were kept at room temperature for $10 \mathrm{~min}$. 
The experiment was repeated using $200 \mu \mathrm{l}$ of each buffer at different $\mathrm{pH}$ values. The labeling yield at each $\mathrm{pH}$ was measured and the $96.5 \%$ was obtained at $\mathrm{pH} 8$. Increasing the $\mathrm{pH}$ of the medium above 8 led to a slight decrease in the iodination yield $95.5 \%$ at pH 9 (Figure 4).

\section{Effect of reaction time}

The labeling yield is strongly dependent on reaction time in the range from 2 to $30 \mathrm{~min}$. It is evident from figure 5 that the yield was significantly increased as the reaction time increased. The reaction was very fast and after $10 \mathrm{~min}$, the maximum radiochemical yield $96.5 \%$ was obtained.

\section{In vitro stability of ${ }^{125}$ | BPA}

The in vitro stability of ${ }^{125}$ I-BPA was studied to determine the most suitable time for injection to avoid the formation of the undesired products that resulted from the radiolysis of the labeled compound. In vivo, these undesired radioactive products might be accumulated in non-target organs. As shown in Figure 6, no significant changes in the relative content of ${ }^{125}$ I-BPA were observed for up to $24 \mathrm{~h}$ post labeling, indicating that the labeled compound is very stable (Figure 6).

The biodistribution pattern of ${ }^{125}$ I-BPA is shown in table $1 .{ }^{125}$ I-BPA was injected in normal mice intravenously and was distributed throughout the body organs and fluids. All radioactivity levels are expressed as the average percentage of injected dose per gram (\% ID/g \pm SD). The biodistribution data showed substantial uptake of the imaging agent at $6.54 \pm 0.10(\% \mathrm{ID} / \mathrm{g} \pm \mathrm{SD})$ in the brain at $30 \mathrm{~min}$ post-injection. After this time, the point radioactivity dropped to $0.09 \pm 0.01$ at $120 \mathrm{~min}$ post-injection. The high amounts of radioactivity in the intestine indicated that excretion of the ${ }^{125}$ I-BPA

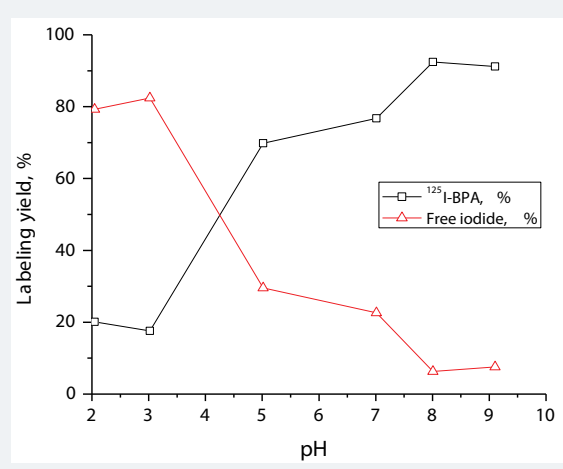

Figure 4: Variation of the radiochemical yield of ${ }^{125} \mathrm{I}-\mathrm{BPA}$ as a function of $\mathrm{pH}$. The reaction conditions were 10 $\mu \mathrm{g}(7.3 \mathrm{MBq}) \mathrm{Na}^{125} \mathrm{l}, 100 \mu \mathrm{g}$ of BPA, and $250 \mu \mathrm{g}$ of CAT at various $\mathrm{pHs}$. The reaction mixtures were kept at room temperature for $10 \mathrm{~min}$.

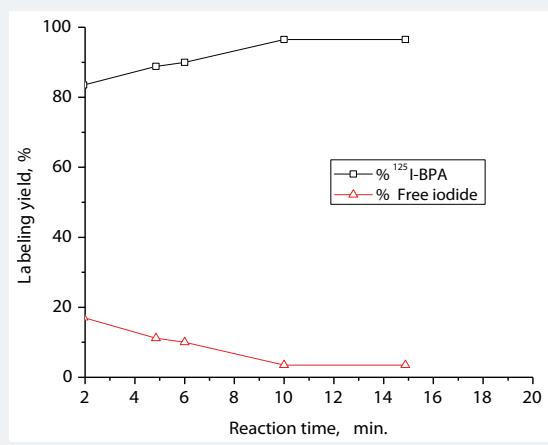

Figure 5: Variation of the radiochemical yield of ${ }^{125}$-BPA as a function of reaction time. The reaction conditions were $10 \mu \mathrm{g}(7.3 \mathrm{MBq}) \mathrm{Na}^{125} \mathrm{I}, 100 \mu \mathrm{g}$ of BPA, and $250 \mu \mathrm{g}$ of CAT at $\mathrm{pH}$ 8. The reaction mixtures were kept at room temperature for the indicated intervals of time. 


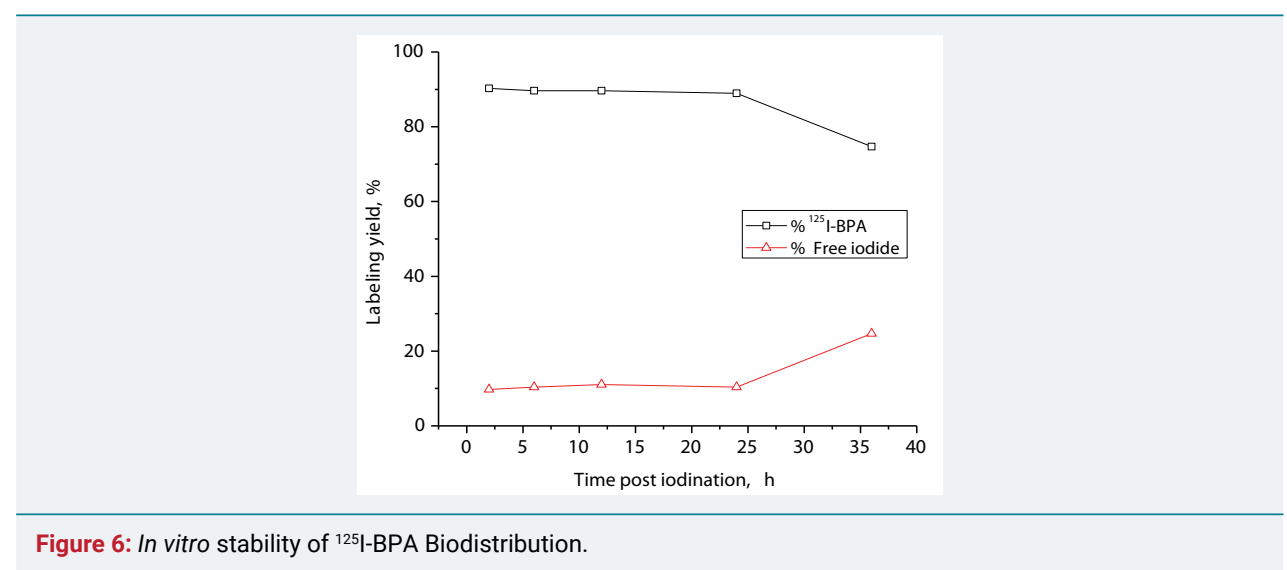

Table 1: Biodistribution of ${ }^{125}$ - BPA in normal mice.

\begin{tabular}{|c|c|c|c|c|}
\hline \multirow{2}{*}{ Organs \& body fluids } & \multicolumn{4}{|c|}{ Injected dose/gram at different time intervals \% } \\
\cline { 2 - 5 } & $\mathbf{5}$ min. & 15 min. & 30 min. & 120 min. \\
\hline Blood & $7.93 \pm 0.90$ & $4.84 \pm 0.40$ & $2.90 \pm 0.17$ & $0.94 \pm 0.10$ \\
\hline Brain & $1.54 \pm 0.10$ & $2.59 \pm 0.10$ & $6.3 \pm 0.1$ & $0.09 \pm 0.01$ \\
\hline Heart & $3.75 \pm 2.20$ & $2.38 \pm 0.04$ & $1.00 \pm 0.1$ & $0.36 \pm 0.10$ \\
\hline Liver & $27.20 \pm 2.8$ & $28.76 \pm 3.31$ & $15.71 \pm 3.7$ & $8.08 \pm 3.54$ \\
\hline Spleen & $5.37 \pm 0.33$ & $3.61 \pm 0.40$ & $1.33 \pm 0.2$ & $0.55 \pm 0.10$ \\
\hline Lung & $7.83 \pm 0.63$ & $4.18 \pm 0.54$ & $2.10 \pm 0.4$ & $0.89 \pm 0.20$ \\
\hline Kidney & $11.94 \pm 1.2$ & $8.47 \pm 0.60$ & $4.87 \pm 1.3$ & $1.16 \pm 0.12$ \\
\hline Stomach & $2.08 \pm 0.42$ & $5.70 \pm 1.01$ & $7.44 \pm 2.4$ & $4.27 \pm 2.40$ \\
\hline Intestine & $3.53 \pm 0.64$ & $17.46 \pm 2.0$ & $29.75 \pm 2.0$ & $40.83 \pm 4.8$ \\
\hline Thyroid & $0.10 \pm 0.03$ & $1.27 \pm 0.10$ & $1.78 \pm 0.10$ & 0.040 .11 \\
\hline
\end{tabular}

derivative occurred mainly through the hepatobiliary pathway. The low radioactivity located in the thyroid gland indicates that the iodocompounds are stable against in vivo deiodination. The high accumulation of ${ }^{125}$ I-BPA in the lungs is likely because the lungs function as a reservoir for antidepressants with high affinity to the serotonin transporter. The biodistribution data showed substantial lung uptake of $4.18 \pm 0.54$ (\% $\mathrm{ID} / \mathrm{g} \pm \mathrm{SD}$ ) at 15 min post injection. The maximum brain uptake of ${ }^{125} \mathrm{I}-\mathrm{BPA}$ is analogous to that of the currently used radiopharmaceuticals for brain imaging, ${ }^{99 \mathrm{~m}} \mathrm{Tc}-\mathrm{ECD}$ and ${ }^{99 \mathrm{~m}} \mathrm{Tc}-\mathrm{HMPAO}$, which have maximum brain uptake of 4.7 and $2.25 \%$, respectively. These preliminary results strongly suggest that BPA labeled with ${ }^{125}$ I could be used as a novel agent for brain imaging.

\section{Conclusion}

BPA was successfully synthesized and radiolabeled with ${ }^{125}$ I using CAT. ${ }^{125}$ I-BPA showed good in vitro stability. In biodistribution experiments using normal mice, ${ }^{125}$ I-BPA displayed good uptake into the brain followed by fast clearance. Radioactivity was also distributed to several other organs, such as the liver, kidneys, and intestines. In addition to accumulating in the brain, the lungs and stomach showed an initial high uptake resulting in moderate accumulation over time, while the liver and kidneys accumulated radioactivity over the first 15 minutes followed by a rapid decrease. The radioactive probe accumulated in the intestines and did not wash out over the period monitored in this experiment.

\section{References}

1. Liu H, Li Y, Wang $X Y$, Wang B, He HY, et al. Synthesis, preliminary structure-activity relationships, and in vitro biological evaluation of 6-aryl-3-amino-thieno[2,3-b]pyridine derivatives as potential antiinflammatory agents. Bioorg Med Chem Lett. 2013; 23: 2349-2352. Ref.: https://goo.gl/ha7K5a

2. Crombie AL, Sum FW, Powell DW, Hopper DW, Torres N, et al. Synthesis and biological evaluation of tricyclic anilinopyrimidines as IKKbeta inhibitors. Bioorg Med Chem Lett. 2010; 20: 3821-3825. Ref.: https://goo.gl/QLUoYB 
3. Pevet I, Brulé C, Tizot A, Gohier A, Cruzalegui F, et al. Synthesis and pharmacological evaluation of thieno[2,3-b]pyridine derivatives as novel c-Src inhibitors. Bioorg Med Chem. 2011; 19: 2517-2528. Ref.: https://goo.gl/hoQ45G

4. Abdel-Rahman AE, Bakhite EA, Al-Taifi EA. Synthesis and antimicrobial testing of some new S-substituted-thiopyridines, thienopyridines, pyridothienopyrimidines and pyridothienotriazines. Die Pharmazie. 2003; 58: 372-377. Ref.: https://goo.gl/JBgTTo

5. Bakhite EA, Abdel-Rahman AE, Mohamed OS, Thabet EA. Synthesis, reactions and antimicrobial activity of new cyclopenta[e]thieno[2,3-b]pyridines and related heterocyclic systems. Die Pharmazie. 2000; 55: 577-583. Ref.: https://goo.gl/aafrQM

6. Khobragade CN, Bodade RG, Konda SG, Dawane BS, et al. Synthesis and antimicrobial activity of novel pyrazolo[3,4-d]pyrimidin derivatives. European journal of medicinal chemistry. 2010; 45: 1635-1638. Ref.: https://goo.gl/JkfBsg

7. Siddiqui ZN, Musthafa TN, Ahmad A, Khan AU. Thermal solvent-free synthesis of novel pyrazolyl chalcones and pyrazolines as potential antimicrobial agents. Bioorg Med Chem Lett. 2011; 21: 28602865. Ref.: https://goo.gl/pi7dUq

8. el-Emary TI, Bakhite EA. Synthesis and biological screening of new 1,3-diphenylpyrazoles with different heterocyclic moieties at position-4. Die Pharmazie. 1999; 54: 106-111. Ref.: https://goo.gl/o3qVbA

9. Manjula PS. Sarojini BK. Narayana B, Darshan Raj CG. An exploration on the synthesis and bioapplications of derivatives of heterocyclic mannich bases. J Fundam Appl Sci. 2016; 8: 115-175. Ref.: https://goo.gl/wSwYUE

10. Ono M, Saji H. SPECT Imaging Agents for Detecting Cerebral $\beta$-Amyloid Plaques. Int J Mol Imaging 2011; 543267. Ref.: https://goo.gl/kaoq2L

11. Cao K, Farahi M, Dakanali M, Chang WM, Sigurdson CJ, et al. Amino Naphthalenyl-2-Cyano-Acrylate (ANCA) Probes Fluorescently Discriminate between Amyloid- $\beta$ and Prion Plaques in Brain. Journal of the American Chemical Society. 2012; 134: 17338-17341.

12. Monsonego A, Zota $\mathrm{V}$, Karni A, Krieger Jl, Bar-Or A, et al. Increased T cell reactivity to amyloid $\beta$ protein in older humans and patients with Alzheimer disease. J Clin Invest. 2003; 112: 415-422. Ref.: https://goo.gl/fJcA9G

13. Ono M, Saji H. SPECT Imaging Agents for Detecting Cerebral \&\#x03B2;-Amyloid Plaques. International Journal of Molecular Imaging 2011.

14. Zhang J, Zhou X, Qin X. Preparation, quality control and physico-chemical properties of 99mTc-BATAV-45. J Radioanal Nucl Chem. 2012; 292: 1377-1383. Ref.: https://goo.gl/MCbMGp

15. Mahlangu O, Mamba B, Momba M. Efficiency of Silver Impregnated Porous Pot (SIPP) Filters for Production of Clean Potable Water. Int J Environ Res Public Health. 2012; 9: 3014-3029. Ref.: https://goo.gl/wS8YLW 